\title{
Improvement of ERP Sand Table Simulation Operation Based on
}

\section{Network Platform}

\author{
Jing $\mathrm{CaO}^{1, \mathrm{a}}$, Hanwen $\mathrm{Liu}^{2, \mathrm{~b}}$, Lin $\mathrm{Yi}^{3, \mathrm{c}}$ \\ 1 School of Accounting, Dianchi College of Yunnan University, Yunnan, China; \\ 2School of Management, University of Otago, Dunedin, New Zealand. \\ 3. School of Business and Management, College of Arts and Sciences - Yunnan Normal University, \\ Yunnan, China
}

a.84495166@qq.com, b.32751918@qq.com,c.605647092@qq.com

Keywords: Network platform; ERP; Simulation business

\begin{abstract}
ERP sand table simulation business offer students through the role-play in the virtual market environment, which experience manufacturing business process. In the ERP sand table simulation business process, students knowledge, individual differences, teaching time and other factors will affect the effect of the course. Based on the network platform, flip classroom can be introduced in ERP sand table simulation confrontation which effectively optimize the existing curriculum design, meanwhile, based on the network platform could through the construction of virtual communities to effectively expand the curriculum.
\end{abstract}

\section{Introduction}

Enterprise Resource Planning is a management philosophy of the supply chain proposed by the US Computer Technology Consulting and Assessment Group-Gartner Group Inc. It is a management platform based on information technology, using systematic management ideas for enterprises Decision-making level and staff to provide decision-making operation method. ERP as a business data center could provide basic data for enterprises accurate and real-time. With the advent of the cloud era, information technology would become a new advantage after the cost advantage; therefore, it would promote enterprise to the intelligent, agile, open and service forward.

As the cradle of cultivating talents, universities have always attached importance to the combination of theory and practice. ERP sand table simulation business was originally developed by the Swedish Royal Institute of Technology in 1978, since 2002, universities have started to establish professional management "ERP sand table experimental center." The implementation of the sand table simulation business has opened up a new way of talent people training. The development of "ERP sand table simulation business" course has become an important part of the reform and management system of management and practice teaching. It can even be said that it has become a preferred course in professional practice teaching in economics and management area.

\section{The Characteristics of ERP Sand Table Simulation Operation}

ERP sand table simulation against could simulate a whole manufacturing enterprise business process, while introduction of different positions of role-playing will allow students to understand the industrial enterprises business-oriented is how to carry out and through all process of the work and staff to complete the corresponding business. 
The course covers management knowledge and skills in business strategy, product development, production management, marketing, financial management etc. ERP sand table simulation business based on the physical sand table or electronic sand table as a teaching aids to create a virtual competitive environment, so that students were held as different roles, which could let enterprise's internal and external environment is abstracted as a specific operating rules. Under the guidance of the common operating rules, the simulation enterprises make their own development business decisions and starting key business, simulation enterprises complete the main business activities around 4-6 years, the basic process shown in Figure 1.

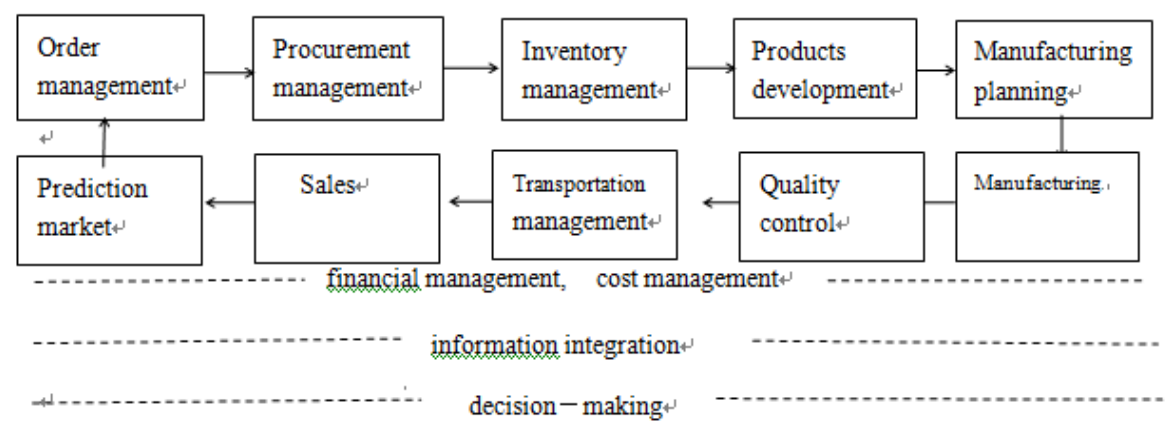

Figure 1 ERP basic process

Compared with the traditional curriculum, ERP sand table simulation has its particularity.

1.Experiential teaching. ERP simulation business using a simplified form of corporate organization, students need to have a clear role in the distribution of business, through the division of labor to do decision-making, and bear the corresponding responsibility. The student is the real subject, and the teacher plays the role of the guide, the companion and the referee.

2. Centralized teaching. ERP sand table simulation is usually concentrated in 2 to 3 days, students need to complete 4 to 7 years of continuous operation, centralized teaching would ensure that students are highly excited state and the maximum mobilization of students learning interest. The particularity of ERP sand table simulation determines the practice of the course, it is trying to allow students to participate in the simulation business in a short period of time, which apply, test and consolidate their expertise, meanwhile, students would feel the complexity of the business environment and more degeneration, to enhance their comprehensive ability eventually.

\section{The Main Problem of ERP Sand Table Simulation Operation}

1. Students' lack of knowledge could effect sand table confrontation. ERP sand table simulation is an all-round demonstration of the management of enterprise managers; it requires participants having relevant theoretical knowledge, specifically, including strategic management, marketing, production operations management, accounting, financial management, human resources management, etc. Accounting students as a result of professional constraints caused the lack of knowledge of strategic management, marketing, logistics operation in the practice, they could not show the ability of strategic planning, market research, market positioning and other basic work in the simulation which limit student ability in the sand table simulation, nor fully embody the guiding role of theoretical knowledge in practice.

2. Students' individual differences affect teaching effectiveness. The knowledge structure of the students and the understanding of the rules will affect the teaching effect to a certain extent. Taking the sand table rules as an example, ERP sand table simulation requires the simulation enterprises to compete under the same initial conditions and established rules. Only familiar with the rules can be running legal business, survive in the virtual market, and development. However, because of the individual differences of students, resulting in the understanding of the rules and grasp the speed 
and depth of the asynchronous, part of the students feel that the progress of teaching too slow, and taking up valuable time in simulation business combat, while the other part of the students were operating process as " Waddle ", thus affecting the normal operation of the simulation business.

The expectation of the practice of ERP sand table simulation practice is helping students testing and using comprehensive knowledge to solve the problems in business, on the other hand allow students have the opportunity to understand the key business processes and core modules. Moreover, the expectation of the simulation offers students to find their own gaps in the knowledge structure and the lack of knowledge in practice in time. But in fact, ERP sand table simulation still remains in a process of vigorous of "around the rules of the game."

3. The contradiction between teaching process and teaching time. ERP sand table simulation practice teaching consists of three main aspects: first of all, the rules explanation and leading the initial year; secondly, the simulation business confrontation; finally, business reviews and summary. Three links are inseparable, which serve the teaching objectives; noteworthy, the second part of the practice teaching is core link. However in teaching process, to explain the rules and to do the initial year leader often need to take half a day to a day, business reviews and summary often can be only allocated by very few hours. This lead to the first stage greatly squeeze the time of students in simulate operation, and the teaching and practice of third stage is not enough, which might cause students loss the opportunity from emotional experience to rational cognitive opportunities.

\section{Improvement Measures of ERP sand table Simulation Operation Based on Network Platform}

1. Designing of ERP sand table simulation management teaching process based on network platform

Flipped classroom can be bought in ERP sand table simulation confrontation based on network platform, so that can effectively expand the teaching capacity, but also to meet the individual needs of students learning. On the one hand, through flipped classroom offers the knowledge of theory and rules explanation 'moving forward', so that win more time in the simulation business, furthermore, flipped classroom can also deepen the depth of business reviews after class, which offer students' emotional experience rose to rational understanding in business operating. On the other hand, students can supplement the lack of theoretical knowledge before the sand table simulation and during the simulation process according to their knowledge structure and interest; meanwhile students could manage their study times and rhythm.

(1). Pre-class preparation

At the beginning of the course, teaching video is produced by the teaching team. It is suggested that teachers and sand table suppliers should co-produce teaching videos, which will be divided into three categories: course introduction, theoretical knowledge and operating rules. To theoretical knowledge, for example, the theoretical knowledge can be divided into sub-categories involved in the operation, such as strategic planning, marketing, production operations, product development, financial management etc., each video duration is about 15 minutes.

Students form a team before class, assign roles, and learn based on their roles.

(2). The main teaching process designing

(a). Qualification assessment .Pre-qualification examination should base on the role of students' role, including theoretical knowledge and operating rules, students who failure the assessment should learn from video again.

(b)Tutorial for Q\&A .Teachers would centralize answer students' questions in the early video learning.

(c) Students starting business simulation. By flipping class, which offers students have more time 
in the classroom to participate in key learning sessions, teachers as "coaches" to accompany students and provide advisory advice.

(4) Comments. After the simulation confrontation, teacher introduces the evaluation method of business performance, and shows the final operating results and performance ranking to students.

(3) Study extension

(a)Classic business case study analysis

Based on class time constraints, teacher only comments the business results within the class, sometimes even just formalism that only a simple data display and analysis, which makes the effect of the curriculum greatly, reduced. However, through the flip class could effectively expand the breadth and depth of evaluation.

Firstly, classic cases selected by teachers can cross the class restrictions, grade restrictions, professional restrictions, but also can refer to use past national, provincial race to analyze the case, so that make cases more abundant; Secondly, using statistical software can be considered based on the network platform, such as using statistical analysis method (such as factor analysis method) to evaluate simulated enterprise by using multiple comprehensive indexes to analyze the operating status which let analysis be more comprehensively and objectively.

(b)Experience sharing and lessons learned. Thoughts of students are recorded and spread through the flip class after class, so that participants could contribute their learning experiences, and enrich the course content, moreover, it would make the experience and lessons can be saved for later reference.

2. Development of ERP sand table simulation business course based on network platform

Network platform can effectively optimize the original course links; meanwhile, network platform can also build a virtual community to expand curriculum effectively. Virtual communities are divided into internal and external communities.

The internal community is mainly for teachers and students to communicate. Business plan could be discussed as well as the curriculum construction by teachers and students, the main function of the internal community is mainly to encourage the exchange of teachers and students, also encourage students to participate in various forms of curriculum construction, which offer students from the passive knowledge to initiative explorers, also provide teachers and students to build a better course construction.

External community mainly for two types of people: first of all, ERP software developers and enterprises; second of all, other colleges and universities. ERP is not just a software and database, it should be regarded as a concept and method, as well as need to advance with times, and ERP should combine the enterprise implementation. As the discuss above, in external community, invited industry experts, business people to share the status of ERP development and trends, sharing ERP practical problems in the enterprise implementation. So that the course can combine with "virtual" and reality, and offer students grasp the actual ERP utilizing more accurately and development trends. Meanwhile, external community also open to other colleges and universities could expand the field of communication, so that more teachers and students could exchange experience in the platform, on the other hand can use the platform to organize ERP simulation business confrontment. With the further development of network technology and ERP simulation software development and application, the future simulation of ERP operations will no longer shackles in the physical sand table and confined to one university or single region or even a country, there will be more people as virtual team with internet to start business simulation business confrontation, thereby enhancing the impact of ERP simulation business.

With the network platform, the process of confront course of ERP sand table simulation can be 
optimized to enhance the effect of simulation operation. Furthermore, the curriculum capacity can be expended effectively by API, which offers students understanding essence of ERP better and grasp the core elements and key processes in industry enterprises, as well as enhance ERP simulation business attractive and influence in a wider range.

\section{Reference}

[1] Huifeng Zhang. An Empirical Analysis of Satisfaction Degree in sand table Simulation Experiment Teaching in Universities [J]. Modern Educational Technology, 2010, 20(4): 127-131.

[2] Bo Chen, Shuding Jia. Discussion of ERP Simulated Operation Teaching [J]. Accounting Monthly. 2011, (04): 103-105.

[3] Ai Xu, Shufeng Gao, Heqin Zhao. The Construction of ERP Comprehensive Practice Teaching System for Economics and Management area [J]. Laboratory Research and Exploration, 2012, 31 (2), 185 - 188.

[4] Zhou Ye. Comparative Analysis and Application of ERP sand table Model Defect [J]. Journal of Economic Research, 2010, 101 (27): 278-279.

[5] Bin Chen. Decision-making and Improvement in Sand Table Teaching System [J]. Laboratory Research and Exploration, 2010, (1): 174-177.

[6] Jingyuan Zhan, Yue Zhao, Dongdi Wang. "Four-stage" teaching method of "Business Sand Table Simulation Operation and Confrontation" Course [J]. Laboratory Research and Exploration, 2011, 30 (3): 365-368.

[7]Bo Chen, Shuding Jin. Discussion of Teaching of ERP Simulated Operation [J]. Accounting Monthly. 2011, (04): 103-105.

[8]Baodi Jia. Problems and Countermeasures in Practice of ERP sand table Simulation [J]. Accounting Friend, 2012 (1): 121-123. 